\title{
A Racionalidade na Interpretação e Aplicação do Direito: do Desafio Kelseniano ao Desafio dos Bons Argumentos
}

\author{
RATIONALITY In THE INTERPRETATION AND APPLICATION OF \\ LaW: from Kelsen's Challenge to the Challenge of \\ Good Arguments
}

\section{Rationalidad EN la INTERPRETACión y ApliCACIÓN DE LA Ley: desde el Desafio de Kelsen hasta el Desafio de los Buenos Argumentos}

\author{
Andreas Joachim Krell \\ Vítor Mendonça Maia**
}

\begin{abstract}
1 Introdução. 2 O "desafio kelseniano" e a falta de cientificidade da interpretação jurídica. 3 A separação rígida entre Direito e Moral. 4 A indevida fixação em um modelo único de ciência; o Direito como ciência prática. 5 A possibilidade de um discurso de justificação sobre juízos de valor na ciência do Direito. 6 A prevalência da vontade na interpretação/ aplicação do Direito e a obrigatória justificação das decisões judiciais. 7 A "moldura normativa" e a "única resposta correta" como posições extremadas; a justificação racional da decisão jurídica. 8 O relativismo de conteúdo do Direito posto e a incomensurabilidade valorativa. 9 Pode haver objetividade na interpretação/aplicação do Direito nos casos de valores em disputa? A importância dos "bons argumentos". 10 A função da dogmática jurídica: da observação à participação no processo de interpretação/aplicação do Direito. 11 Conclusão. Referências.
\end{abstract}

\footnotetext{
Doctor Juris pela Freie Universität Berlin(Alemanha). Professor Titular de Direito Ambiental e Constitucional da Faculdade de Direito da Universidade Federal de Alagoas (FDA/UFAL), nos cursos de Graduação e Mestrado em Direito. Coordenador do Mestrado em Direito da UFAL. Professor permanente do PPGD da Faculdade de Direito do Recife (UFPE). Pesquisador bolsista do CNPq (PQ1A). Consultor da CAPES. Universidade Federal de Alagoas - UFAL Maceió, AL, BR. E-mail: <akrell@uol.com.br>.http://orcid.org/0000-0002-4394-4867

"Bacharel em Direito pela Faculdade de Direito de Alagoas (FDA) da Universidade Federal de Alagoas (UFAL). Mestre em Direito pela FDA/UFAL. Assessor de Juiz do Tribunal de Justiça de Alagoas, Maceió, AL, BR. E-mail: <vito_maia@hotmail.com>. https://orcid.org/0000-0002-1235-5007
} 
A racionalidade na interpretação e aplicação do direito: do desafio kelseniano ao desafio dos bons argumentos

\section{RESUMO}

Objetivo: Buscamos demonstrar a necessidade de superação do "desafio kelseniano" referente à pretensa impossibilidade de racionalidade na interpretação e aplicação do Direito. Procuramos questionar o modelo kelseniano de ciência para a área jurídica e investigar se há uma objetividade no uso de "bons argumentos" capaz de impor um maior padrão de racionalidade aos operadores jurídicos brasileiro no momento da tomada de decisão.

Metodologia: Partimos de uma pesquisa jurídica mais tradicional (embora não dogmática), baseada em uma resenha bibliográfica crítica de doutrina nacional e estrangeira. Compreendemos a ciência jurídica como uma ciência de ação que deve oferecer caminhos teóricos viáveis para a tomada de decisões e a solução de problemas concretos.

Resultados: Concluímos que a ideia de Kelsen sobre a interpretação do Direito é resultado do seu conceito positivista de ciência, baseado na comprovação empírica das ciências exatas. A sua distinção rígida entre juízos de fato e juízes de valor (inacessíveis para o conhecimento científico) e afirmação da prevalência da vontade sobre a racionalidade no ato de interpretar/aplicar uma lei entram em conflito com o dever constitucional de fundamentação racional das decisões judiciais.

Contribuições: Levantamos argumentos contra uma visão relativista da interpretação do Direito, que contribui para a imprevisibilidade das decisões judiciais. Esclarecemos diferentes aspectos da teoria de Kelsen que versam sobre a interpretação e aplicação da lei que são pouco discutidas na academia do Direito brasileiro.

Palavras-chave: Desafio kelseniano. Conceito positivista de ciência. Justificação racional. Incomensurabilidade de valorações. Bons argumentos.

\section{ABSTRACT}

Objective: We seek to demonstrate the need to overcome the "Kelsenian challenge" regarding the alleged impossibility of rationality in the interpretation and application of law. We pretend to question the Kelsenian model of science for the legal area and investigate whether there is an objectivity in the use of "good arguments" capable of imposing a greater standard of rationality on Brazilian legal operators at the time of decision making.

Methodology: We start from a more traditional (although not dogmatic) legal research, based on a critical bibliographic review of national and foreign doctrine. We understand legal science as a science of action that must offer viable theoretical paths for decisionmaking and concrete problem solving. 
Results: We conclude that Kelsen's idea of the interpretation of law is the result of his positivist concept of science, based on empirical proof of the exact sciences. His rigid distinction between judgments of facts and of values (inaccessible to scientific knowledge) and his affirmation of the prevalence of will over rationality in the act of interpreting/applying the law conflicts with the constitutional obligation of rational reasoning of judicial decisions.

Contributions: We raise arguments against a relativistic view of the interpretation of law, which contributes to the unpredictability of judicial decisions. We clarify different aspects of Kelsen's theory that deal with the interpretation and application of the law that are little discussed in the Brazilian academy of law.

Keywords: Kelsenian Challenge. Positivist concept of science. Rational justification. Incommensurability of values. Good arguments.

\section{RESUMEN}

Objetivo: Buscamos demostrar la necesidad de superar el "desafío kelseniano" con respecto a la supuesta imposibilidad de racionalidad en la interpretación y aplicación del derecho. Tratamos de cuestionar el modelo de ciencia kelseniana para el área jurídica e investigar si existe una objetividad en el uso de "buenos argumentos" capaces de imponer un mayor nivel de racionalidad a los operadores legales brasileños en el momento de la toma de decisiones.

Metodología: Comenzamos a partir de una investigación legal más tradicional (aunque no dogmática), basada en una revisión bibliográfica crítica de la doctrina nacional y extranjera. Entendemos la ciencia jurídica como una ciencia de acción que debe ofrecer caminos teóricos viables para la toma de decisiones y la resolución concreta de problemas.

Resultados: Concluimos que la idea de Kelsen de la interpretación del derecho es el resultado de su concepto positivista de la ciencia, basado en la prueba empírica de las ciencias exactas. Su rígida distinción entre las sentencias de hecho y los jueces de valor (inaccesibles para el conocimiento científico) y la afirmación de la prevalencia de la voluntad sobre la racionalidad en el acto de interpretar/aplicar una ley entra en conflicto con el deber constitucional de razonamiento racional de las decisiones judiciales.

Contribuciones: Planteamos argumentos contra una visión relativista de la interpretación del derecho, que contribuye a la imprevisibilidad de las decisiones judiciales. Aclaramos diferentes aspectos de la teoría de Kelsen que se ocupan de la 
A racionalidade na interpretação e aplicação do direito: do desafio kelseniano ao desafio dos bons argumentos

interpretación y aplicación de la ley que se discuten poco en la academia brasileña de derecho.

Palabras clave: Desafío Kelseniano. Concepto positivista de la ciencia. Justificación racional. Inconmensurabilidad de las evaluaciones. Buenos argumentos.

\section{INTRODUÇÃO}

Os conceitos fundamentais da Teoria Pura do Direito, principal obra de Hans Kelsen (1881-1973), até hoje, integram a Teoria Geral do Direito e influenciam o imaginário coletivo da dogmática jurídica no Brasil. No entanto, há muitos que atuam profissionalmente nessa área ou estão se formando nos cursos de (pós-)graduação em Direito, que não conseguem compreender o modelo kelseniano de ciência na sua complexidade. Especialmente as suas lições sobre a interpretação jurídica foram pouco discutidas na doutrina e representam uma incógnita para muitos que atuam na área do Direito, dos quais uma parte associa ao juspositivismo e ao próprio nome de Kelsen uma interpretação mecânica, meramente literal das palavras da lei.

A interpretação/aplicação 1 do Direito é um dos temas mais controversos nas discussões e pesquisas jurídicas atuais, preocupadas com a sua praticabilidade, previsibilidade, produção de decisões justas na base de critérios objetivos ou os limites materiais do controle judicial de atos públicos. Talvez o maior desafio contemporâneo resida no enfrentamento construtivo da imprevisibilidade das decisões dos órgãos públicos.

Foi chamada de "desafio kelseniano" a concepção do autor austríaco sobre a interpretação e aplicação do Direito, tendo em vista as objeções presentes em sua obra à possibilidade de um conhecimento racional substancial sobre esse ato. Superar o "desafio kelseniano" passa a ser condição de um conhecimento racional sobre a concretização do Direito, tendo em vista as quatro objeções feitas por Kelsen: a) a ausência de verdade nos juízos de valor; b) a interpretação autêntica dominada pela vontade; c) a impossibilidade de descrição das possibilidades do enunciado jurídico além da sua moldura; e d) o relativismo de conteúdo do Direito.

Kelsen adota um conceito bastante limitado de ciência para aplicá-lo na área do Direito, o que leva a muitas dificuldades práticas. Aqueles que até hoje defendem, pelo menos em parte, o modelo de "ciência jurídica" proposto por ele entre os anos 30 e 60 do século passado, não conseguem oferecer respostas às questões mais prementes da atualidade no âmbito da interpretação e aplicação do Direito.

\footnotetext{
${ }^{1}$ Entendemos que, na interpretação do Direito, "o conhecimento do sentido de um texto jurídico e sua aplicação a um caso jurídico concreto não são dois atos separados, mas um processo unitário." (GADAMER, 2004, p. 409).
}

88 - R. Opin. Jur., Fortaleza, ano 19, n. 32, p.85-116, set./dez. 2021 
Discutir os limites de um conhecimento racional da interpretação/aplicação do Direito não se confunde com a afirmação de que esse processo seja exclusivamente baseado em questões cognitivas. A possibilidade da construção desse conhecimento capaz de transpor a Teoria do Direito ao campo prático precisa ser confirmada também perante algumas considerações metaéticas, visto que esse ramo da Filosofia passou a discutir, nas últimas décadas, justamente a questão das valorações, que guarda íntima relação com a interpretação do Direito.

O Brasil estabeleceu o dever jurídico expresso de fundamentação das decisões do Poder Judiciário e da Administração Pública, o que revela a preocupação com a racionalidade da aplicação do Direito como forma de seu controle. Por isso, as objeções levantadas por Kelsen serão confrontadas para verificar a possibilidade de superar o “desafio kelseniano" e, em caso positivo, se a questão está definitivamente solucionada.

O estudo doutrinário sobre o tema contempla, ao lado dos doutrinadores nacionais mais expressivos, as publicações de autores estrangeiros, especialmente alemães, a fim de demonstrar que a discussão sobre os constrangimentos e as potencialidades da teoria positivista de matiz kelseniano já avançou bastante em outros países.

\section{O "DESAFIO KELSENIANO" E A FALTA DE CIENTIFICIDADE DA INTERPRETAÇÃO JURÍDICA}

Ferraz Júnior (2016, p. 217ss.) chamou de "desafio kelseniano" o capítulo VIII da obra Teoria Pura do Direito que trata da interpretação jurídica, acrescentado à sua segunda edição, em 1960. Analisar as razões que levaram o autor a cunhar essa expressão é o primeiro passo para entender a importância desse "desafio" a uma teorização acerca da interpretação jurídica e para uma teoria da decisão jurídica. Segundo ele, Kelsen concluiu não ser possível falar da correção (ou retidão) de uma interpretação, em termos de verdade/falsidade, já que, na definição de sentido de uma norma, a vontade prevalece sobre o conhecimento. Além disso, o mestre austríaco alegou que as possibilidades interpretativas impedem um tratamento científico da interpretação do Direito para além da chamada "moldura".

Percebemos que o "desafio" precisa ser enfrentado por qualquer um que pretenda afirmar a racionalidade da procura pelos fundamentos da interpretação jurídica; tratá-la em nível teórico pressupõe a superação das conclusões de Kelsen sobre o assunto. Ele negou que possa existir conhecimento científico sobre a interpretação, já que juízos de valor não seriam enquadráveis no esquema verdade/falsidade; ao mesmo tempo, julgou impossível a descrição objetiva de uma interpretação correta do Direito, já 
A racionalidade na interpretação e aplicação do direito: do desafio kelseniano ao desafio dos bons argumentos

que essa seria caracterizada por atos de vontade dos órgãos de aplicação das normas jurídicas (FERRAZ JÚNIOR, 2016, p. 218s.).

Kelsen (1962, p. 283ss.) sustenta um critério formal para distinguir entre o cognoscitivo enquanto conhecimento objetivo (racional, científico) e o subjetivo, resultado de uma opção política. Esse critério é ilustrado pelo par conceitual "interpretação autêntica $x$ interpretação não-autêntica”. A interpretação dos órgãos credenciados pelo sistema jurídico é "autêntica" porque "cria direito", independentemente do conteúdo. Os cidadãos estão vinculados ao resultado, ainda que arbitrário e aleatório; tudo depende da "justeza" da própria lei, fruto da escolha legislativa. Com isso, interpretar autenticamente o Direito nada mais é do que simplesmente aplicá-lo.

Nesse modelo, a função da doutrina jurídica de orientar a prática é bastante reduzida, visto que produziria apenas uma interpretação "não-autêntica”, sem aplicação concreta. Estabelecer decisões justas ou corretas, na visão de Kelsen, é papel da política do Direito. Assim, mesmo que se esteja diante de uma lacuna ou de um caso difícil, a doutrina, para ser científica, deve restringir-se a apontar as possibilidades de sentido e nada mais (KELSEN, 1962, p. 296ss.). Devido à sua coerência metodológica, ele pretendeu descrever o Direito como ele é, desconsiderando fatores reais de sua origem, de maneira que sua teorização acaba privilegiando excessivamente a estrutura do Direito, em prejuízo de sua função. Isso não significa, contudo, que a teoria kelseniana deve ser abandonada por completo, sendo preciso insistir na crítica construtiva, para verificar o que ainda "está vivo" nela (LOSANO, 2010, p. 126ss.).

Parece que essa "parte viva” se refere à explicação estrutural do Direito que, em termos racional-sistemáticos, influenciou inúmeros estudos desde então. A interpretação, contudo, é reduzida pelo autor à política do Direito e a um subjetivismo (“ato de vontade"), cuja distância do racionalismo científico é tão grande que acaba por retirar a interpretação/aplicação do Direito do campo da ciência. O seu pretendido critério científico-racional apto a orientar a produção de uma teoria pura do Direito mostra-se insuficiente diante dos casos concretos, justamente onde o Direito é realizado com mais intensidade na vida das pessoas. A interpretação científica kelseniana resumese às possibilidades de decisão para os casos concretos, sem indicação de qual é efetivamente a melhor em cada situação, no famoso esquema da "moldura". Assim, do ponto de vista prático, sua teoria produz "resultados escassos" (LARENZ, 2014, p. 92).

$\mathrm{Na}$ verdade, Kelsen pretendeu edificar cientificamente o conhecimento jurídico, sem utilização de valores "extrassistêmicos”, não internalizados normativamente, delineando as possibilidades de uma ciência na área do Direito e tentando afastar os elementos metafísicos. Para o positivismo ${ }^{2}$ reinante de sua época, a ciência rejeitava

\footnotetext{
${ }^{2}$ Ultrapassa o escopo deste trabalho a apresentação das diversas correntes do juspositivismo (exclusivo e inclusivo), bem como a discussão das teses de seus principais defensores. $O$ tema aqui abordado se 90 - R. Opin. Jur., Fortaleza, ano 19, n. 32, p.85-116, set./dez. 2021
} 
tudo o que considerava irracional, ideológico ou não reproduzível por experimento ou demonstração lógico-matemática, apesar das diferenças entre o positivismo jurídico e o clássico (LOSANO, 2010, p. 28ss.).

Chiassoni (2017, p. 529), comentando a frase kelseniana de que a Teoria Pura era "uma teoria do Direito positivo em geral", alega que se trata de uma afirmação "modesta demais para ser levada a sério, breve demais para ser verdadeira em relação à pluralidade dos níveis e à riqueza dos conteúdos da filosofia jurídica kelseniana”. A Teoria Pura conteria, além de uma Teoria Geral do Direito, "um nível metateórico e metadogmático, no qual se situa uma epistemologia juridica pura". Ela seria, portanto, uma teoria sobre as condições necessárias para poder considerar a teoria e a doutrina do Direito "atividades genuinamente científicas, idôneas a procurar um conhecimento objetivo e exato do direito positivo".

\section{A SEPARAC̣ÃO RÍGIDA ENTRE DIREITO E MORAL}

A pureza epistemológica exigida por Kelsen, despreocupada com os fins práticos, tem ainda outro preço: o sacrifício total da moral e da justiça, as quais seriam "ideais metafísicos”, impassíveis de considerações científicas. A exatidão e a objetividade do conhecimento atingido pela metodologia kelseniana referem-se apenas ao aspecto da estrutura do Direito, que possui reduzida importância para a resolução dos problemas jurídicos mais difíceis. A obra de Kelsen é importante para entender a estrutura do Direito, mas nada responde à pergunta de como ele deve ser, como ele mesmo afirma. Como no relativismo e no positivismo, o justo e o correto não têm vez nela (ANTISERI; REALE, 2006, p. 28); além disso, não desenvolve uma dogmática da interpretação.

O referido relativismo decorre da admissão de que o Direito é fruto de decisões variáveis no tempo e no espaço, cuja validade encontra sua base em processos formais, de maneira que a contingência começa a ser elemento constante do Direito. A legitimação deste, enquanto sistema, não encontra lastro na razão prática da ação justa, senão no fato de ter havido uma escolha subjetiva em determinado momento e lugar, a fim de se tornar uma ação válida. Por isso, no Direito positivo, as normas passam a ser válidas devido ao tempo e ao espaço em que são postas, de forma indiferente ao justo (DE GIORGI, 2010), em um realismo extremado (CHIASSONI, 2017, p. 514ss.).

No entanto, a relatividade de conteúdo do Direito posto gera dificuldades para a sua legitimação por não levar em consideração o justo. Kelsen legitima, no plano teórico, a validade do Direito contingente, enquanto forma posta, mas não consegue

restringe à crítica da teoria de interpretação de Kelsen, um dos representantes mais importantes do positivismo jurídico, um termo que, em nenhum momento, empregamos na sua forma "caricaturada" (cf. DIMOULIS, 2006, p. 53ss.). 
A racionalidade na interpretação e aplicação do direito: do desafio kelseniano ao desafio dos bons argumentos

legitimar substancialmente o Direito enquanto "concretização de sentido da razão jurídica" no seu aspecto prático, o que poderia impedir construções teóricas do lado negativo da contingência jurídica, como as leis postas pelos governos nazista e fascista (DE GIORGI, 2010, p. 21s.). O relativismo moral é pressuposto teórico da Teoria Pura; ele, contudo, não se confunde com a ideia multiculturalista de que diferentes tradições geram diversos valores. Segundo a concepção epistemológica kelseniana, em uma mesma sociedade, os valores são impossíveis de serem explicados universalmente, mesmo que coincidam, ocasionalmente, certos valores entre diferentes indivíduos (MELLO, 2012).

Nessa linha, a justiça é uma "ideia irracional" diante da impossibilidade de estabelecer previamente, de forma científica, qual o critério de determinação do justo, e a subjetividade inerente às análises de interesses contrapostos. Com isso, Kelsen defende que as disputas entre valores sejam travadas nos parlamentos, em que cada um dos indivíduos pode - pelo menos teoricamente - conquistar a vontade dos demais através de debates. Nesse contexto, a criação do Direito pelo legislador não é ligada a ideais racionais universais; o que interessa, para ele, é o aspecto procedimental-formal da criação. Fica de fora de sua teorização uma busca efetiva por soluções substanciais acerca de tensões envolvendo valores igualmente importantes em um Estado Democrático de Direito, a exemplo das escolhas das maiorias em prejuízo dos direitos de minorias (MELLO, 2012).

Não se desconhece, contudo, que Kelsen, seguindo sua metodologia à risca, entende como teoria da interpretação a indicação das possibilidades interpretativas, ilustrada pela metáfora da moldura. No entanto, com a sua epistemologia jurídica pura, ele deixa de fora da ciência a possível racionalidade da aplicação do Direito, fazendo que exista sempre uma margem de discricionariedade ou até arbitrariedade na aplicação de normas jurídicas, o que é uma das maiores preocupações da interpretação dos direitos fundamentais na atualidade.

\section{A INDEVIDA FIXAC̣ÃO EM UM MODELO ÚNICO DE CIÊNCIA; O DIREITO COMO CIÊNCIA PRÁTICA}

Hoje tornou-se bastante problemático querer limitar a ciência do Direito a uma análise descritiva da legislação ou de seus efeitos sociais, visto que o seu objeto deve ser também o processo da aplicação das leis, e a sua função prática consiste em resolver conflitos por decisões racionais, seus pressupostos, critérios e limites (CALSAMIGLIA, 2000, p. 18ss.). Cabe à ciência jurídica a importante e complexa tarefa de preparar, subsidiar e possibilitar a argumentação discursiva na aplicação do Direito (DECKERT, 1996, p. 53). Tudo indica que não existe uma única ciência jurídica, mas tantas 
"quantas são as imagens que o jurista tem de si mesmo e da própria função na sociedade." (BOBBIO, 2007, p. 37).

A atividade que os juristas normalmente exercem de fato não está fora do âmbito de um possível enquadramento no termo vago ciência; pergunta-se, contudo, qual a utilidade dessa qualificação, já que incluir um fenômeno em uma categoria deve servir a certo propósito. Esse parece ser, sobretudo, o de fornecer ao Direito o mesmo prestígio e "carga emotiva favorável" que se atribui às atividades científicas "clássicas", como a Física, a Química, a Biologia, a Matemática etc. (NINO, 2003, p. 319s.).

Declarar que o Direito é uma ciência (em vez de uma prudência) fortalece os argumentos utilizados no discurso jurídico, emprestando-lhes autoridade e presunção da irrefutabilidade, que o leigo comumente atribui às afirmações científicas. Agindo assim, o jurista também reivindica o status de "teórico" para poder participar de disputas políticas sem precisar submeter-se ao estilo mais rude de discussão e tentar blindar as suas posições contra questionamentos (BALLWEG, 1982). Por isso, muitos juristas, até hoje, tentam "conferir uma roupagem científica" às concepções e práticas prudenciais aptas para fundamentar as suas opções políticas (COSTA, 1998, p. 143-177).

A adesão às lições kelsenianas, sem as devidas adaptações ao Direito contemporâneo, deixa de levar em consideração importantes resultados da discussão justeórica e filosófica após a Segunda Guerra (REALE, 1994), cuja nítida tendência tem sido analisar a questão do caráter científico do Direito a partir do método que emprega, e menos em torno de seu objeto formal, o texto normativo (NEUMANN, 2002). Vale frisar que a reflexão desses autores tem sido "de ordem essencialmente metodológica", sem nenhum lastro em teorias de cunho jusnaturalista (PERELMAN, 2004, p. 113).

Na verdade, a Teoria Pura, que entende o Direito como mero "dever-ser fático", rejeitando a inclusão da dimensão do valor normativo e da perspectiva da efetividade social nos seus objetos de investigação, despreza o próprio ser do Direito e sua complexa relação com o dever-ser e a validade jurídica. Kelsen justifica sua teoria com a necessidade de separar o conhecimento do Direito das disciplinas da Teoria Política, Ética, Sociologia e Psicologia, não porque ela ignorasse sua íntima conexão, mas para evitar um "sincretismo metodológico" que "ofusca a essência da ciência jurídica e distorce os limites, que lhe são traçados pela natureza do seu objeto.” (KELSEN, 1960, p. 1).

Assim, a estrita visão positivista leva à construção de uma teoria meramente formal, para a qual os juízos de valor - denunciados como "irracionais" - jamais podem ser científicos. Todavia, a aplicação das normas jurídicas a casos concretos e a dogmática sempre vão se basear, em grande medida, em um pensamento orientado a valores, fato de que muitos operadores não têm clara consciência, pois não consideram os juízos de valor como suscetíveis de fundamentação racional (LARENZ, 2014). Como a Teoria Pura não se interessa por essa área prática do Direito, ela "vale apenas para um setor 
A racionalidade na interpretação e aplicação do direito: do desafio kelseniano ao desafio dos bons argumentos

marginal dele" (LOSANO, 1996, p. 15). Dessa "ascese de valores", normalmente transparece "o páthos emocional de uma exasperada probidade intelectual" (WIEACKER, 1970, p. 332ss.).

Todavia, para a afirmação apodítica que "não faz sentido" indagar sobre juízos de valor nas decisões jurídicas, basta "restringir suficientemente o conceito de 'sentido' para poder declarar em relação a todas as perguntas incômodas que não se consegue ver algum 'sentido' nelas”. Com pessoas que reconhecem como "razoáveis” apenas questões pertencentes às ciências empíricas, é igualmente "inócua qualquer discussão sobre o conceito do sentido; uma vez entronizado, esse dogma de sentido estará imune a todo o tipo de ataque para sempre” (POPPER, 2004, p. 123).

Quem nega ser possível estabelecer "pautas de preferência para as opções axiológicas” por serem problemas de valor, inacessíveis a critérios racionais, é incapaz de esboçar uma base metodológica para o elemento essencial da prática jurídica: a decisão judicial, considerada por Kelsen um mero ato de vontade. Todavia, a experiência jurídica não pode ser reduzida a formas e estruturas (MURICY, 2002).

É essa natureza do Direito que não combina com uma "ciência pura de espírito", mas clama por uma verdadeira ciência de ação - uma "teoria em serviço da práxis" jurídica -, a qual procura conhecimento teórico em função da decisão prática que se pretende produzir mediante o Direito. Por isso, é coerente ver o objeto da ciência jurídica menos nas regras, mas nos fatos sociais dos quais elas são valorações (BOBBIO, 2007, p. 40). O “próprio objeto de estudo" do cientista do Direito ("jurista”) não é, portanto, a lei, mas a conduta humana à qual ela se refere (AFTALIÓN; VILANOVA, 1994, p. 172s., 340).

Em vez de especular abstratamente sobre a "essência do Direito" para determinar a priori a natureza de seu objeto, essa natureza deveria ser definida a posteriori, a partir de uma análise concreta das experiências com aquilo que diariamente é exercido e considerado como "ciência jurídica". Em face do intenso entrelaçamento temático das esferas do fático e do normativo, interligadas em uma relação dialética de efeitos recíprocos, que tanto inclui fenômenos da determinação ideal causados pela força fática do normativo quanto de determinação real com base na força normativa do fático, podese perguntar se não seriam inevitáveis transgressões metódicas dos limites estreitos de idealidade e realidade, de consciência e fato, de pensar e ser (MAIHOFER, 1972).

Sem dúvida, do ponto de vista científico, tanto o realismo jurídico, que entende o Direito como algo meramente empírico, quanto o "idealismo lógico-jurídico" de matiz kelseniano representam teorias perfeitamente defensáveis. No entanto, ambas as teorias “cortam o Direito pela metade”, suprimindo ou sua dimensão normativa ou seu elemento fático, com a consequência de que a parte omitida é expulsa também do âmbito da própria racionalidade jurídica, assumindo o caráter (mais ou menos) 
irracional, no sentido subjetivo ou político. "Ambas as formas de autolimitação possuem a desvantagem de encurtar - para poder manter um conceito mais pretensioso de ciência - o conceito de racionalidade de tal forma que ele não consegue mais abarcar todo o processo da decisão jurídica” (MASTRONARDI, 2001, p. 183).

A disciplina jurídica, tradicionalmente considerada uma arte, sempre intentou convencer os interessados nas lides judiciais acerca de sua racionalidade. Em tempos modernos, a melhor forma de o Direito alcançar esse fim tem sido provar a sua cientificidade, demonstrada através de uma autêntica metodologia, isto é, um procedimento racional por meio do qual uma assertiva pode ser confirmada ou refutada. O fato de ser a pré-compreensão subjetiva do intérprete que normalmente leva à hipótese de solução do caso, a ser verificada depois mediante a aplicação dos métodos jurídicos, não invalida o caráter científico do Direito, enquanto os pré-juízos que motivaram o julgador são revelados (MASTRONARDI, 2001).

Müller (2008, p. 83) está com razão quando assevera que a objetividade específica da ciência do Direito não pretende alcançar metas, como "utilidade absoluta" ou "cogência lógico-formal", mas tem por meta apenas a "plausibilidade", obrigando aqueles que decidem “à exposição racional das razões da decisão”, o que levará "também a uma maior racionalidade da aplicação do direito".

Assim, o "desafio kelseniano" referente à impossibilidade de se afirmar cientificamente se uma interpretação leva ao "verdadeiro" significado de uma norma jurídica ou conduz à "ruptura anticientificista" do Direito. Desde que todo rigor lógico da Teoria Pura tinha levado apenas a um "resultado pífio", isto é, imprestável para dar suporte à prática da aplicação do Direito, a doutrina jurídica começou a procurar alternativas não exploradas para fundamentar o seu próprio estatuto científico (COELHO, 2013, p. 241ss.).

\section{A POSSIBILIDADE DE UM DISCURSO DE JUSTIFICACุÃO SOBRE JUÍZOS DE VALOR NA CIÊNCIA DO DIREITO}

O termo ciência, historicamente, significa oposição à opinião. Aristóteles entendia a ciência como conhecimento da essência necessária ou da substância, que, por sua vez, levou a um desenvolvimento da ciência em que as suas verdades estavam associadas ao conhecimento da realidade pelos sentidos (tato, olfato, visão, audição, paladar). A ciência era produzida como um conhecimento "verdadeiro" da realidade alcançada pelos sentidos; a fundamentação científica estava assentada em um ideal de "verdade por correspondência” (ABBAGNANO, 2007, p. 136ss.).

Essa verdade se estabelece pela descrição correspondente à realidade experimentada pelos sentidos, uma concepção que limitava bastante as ciências, 
A racionalidade na interpretação e aplicação do direito: do desafio kelseniano ao desafio dos bons argumentos

principalmente onde não fosse possível utilizar apenas os sentidos. A ciência do Direito teria de ignorar por completo a abertura para os valores, como a pretensão de correção, a justiciabilidade, a dignidade humana, entre outros aspectos necessários à solução dos problemas reais, objetos de decisões jurídicas. A abertura da ciência jurídica contemporânea se deu com Viehweg (2008), em 1954, quando analisou criticamente a ideia de um sistema jurídico-científico, até então, predominante.

Ferraz Júnior (2014, p. 13-50) demonstra a dinamicidade do Direito como objeto que está esperando a atuação dos intérpretes, o que impede uma sistematização descritiva. Afinal, o Direito "não nasce da pena do legislador" e apresenta contingências, principalmente nas decisões dos órgãos competentes; mesmo assim, pode ser considerado objeto de uma análise científica. Para enfrentar as necessidades reais, essa ciência deve se abrir para outras formas de conhecimento, como as concepções de verdade por coerência ou por consenso, que permitem ver a aplicação do Direito na prática capaz de ser controlada mediante argumentos. Com isso, retorna-se ao saber prático dos romanos (prudentia), em contraposição à preferência pelo saber puro dos gregos (sapientia), até porque a parte "sistematizável" do Direito já não é problemática (PERELMAN, 2004, 178ss.).

A verdade, tema fundamental da ciência, é ressignificada, o que não leva necessariamente à anarquia metodológica, uma vez que não se abandonam os valores do "verdadeiro" e do "falso" (CARVALHO, 2013, p. 160s.). Embora a verdade não seja mais uma ilusão objetiva, correspondente à dada realidade descrita, ela ainda existe enquanto valor perseguido pela ciência. Agora, passa a ser produzida em relação a um sistema de referência. Por isso, o método, enquanto caminho do conhecimento, passa a ser, ao lado do objeto estudado, uma grande preocupação do cientista, porquanto ele será determinante para a definição de enunciados verdadeiros (FERRAZ JÚNIOR, 2014, p. 4).

Kelsen era influenciado pelo conceito de ciência do positivismo, baseado na comprovação "verdadeira" do conhecimento pela simples descrição, o que o levou a afirmar que juízos de valor não poderiam ser justificados cientificamente. No entanto, basta que se supere esse tipo de ciência como referencial teórico, para que essa (pretensa) impossibilidade seja fortemente enfraquecida, diante da necessidade de se ter um método apropriado para os problemas práticos. Além disso, é questionável a diferença rígida entre fatos e valores, adotada pelo positivismo, que levou Kelsen a distinguir entre a realidade ("ciência") e o juízo de valor ("política").

Essa distinção não se sustenta para quem não considere a ciência uma atividade de mera constatação, mas de construção a partir do paradigma vivenciado, o que abrange as teorias e interpretações. O objeto ou a "realidade" a ser descrita não passa de uma construção do próprio observador, a partir do seu paradigma, tendo em vista que 
não há uma linguagem exclusivamente voltada a relatar "um mundo plenamente conhecido de antemão" que produza "meras informações neutras e objetivas sobre 'o dado" (KUHN, 2013, it. 9). Com isso, fica enfraquecida a visão de que o conhecimento seja apenas um "espelho" da realidade passível de ser descrito pela "mera presença" do observador/cientista (RABENHORST, 2003, p. 51), até porque a descrição verdadeira pressuporia um hipotético ponto de vista do "Olho de Deus", apto a confirmar objetivamente a descrição verdadeira, algo incompatível com a natureza humana (PUTNAM, 1981, p. 49ss.).

A orientação positivista tem de enfrentar um dilema: ou negará a objetividade de todos os valores ou tentará dissociar os valores cognitivos dos valores éticos propriamente ditos. Na primeira escolha, o positivismo terá de admitir a justificação científica como algo puramente subjetivo e, por conseguinte, deixar de ser positivista e passar a ser epistemologicamente relativista. Na segunda escolha, concluirá que inexiste um critério objetivo e seguro para distinguir a linguagem descritiva da valorativa (ex.: a frase "Calígula era um tirano louco" pode ser um julgamento descritivo e verdadeiro, mas também um julgamento de valor). Os termos verdade, simplicidade, pertinência ou coerência revelam que existe um vasto conjunto de interesses e valores nas próprias condições de se julgar um conhecimento como científico, de maneira que um acordo ou desacordo de "fatos" pode ser idêntico a um desacordo de valores (RABENHORST, 2003, p. 54s.).

O conhecimento sobre a interpretação/aplicação das normas jurídicas, enquanto atividades humanas, não pressupõe juízos de valor de forma diferente do que qualquer outra forma de conhecimento, haja vista a própria realidade ser moldada a partir do paradigma vivenciado, ainda que com base em elementos compartilhados de conhecimento. Não se pode dizer que é impossível trabalhar com racionalidade as questões relacionadas à interpretação/aplicação do Direito somente porque elas pressupõem valorações, já que a distinção entre fatos e valores é tão artificial e valorativa como qualquer outro valor. É viável, sim, justificar racionalmente a interpretação na ciência do Direito (“jurisprudência”).

\section{A PREVALÊNCIA DA VONTADE NA INTERPRETAÇÃO/APLICAÇÃO DO DIREITO E A OBRIGATÓRIA JUSTIFICAC̣ÃO DAS DECISÕES JUDICIAIS}

A ideia kelseniana de que a interpretação do Direito tem por base a vontade do aplicador guarda forte relação com a orientação do "não cognitivismo ético" e do "subjetivismo moral”, ambos de orientação positivista. Pelo primeiro, o conhecimento sobre a moral não é possível de forma científica; pelo último, um julgamento moral é resultado dos sentimentos do sujeito (RABENHORST, 2003, p. 34). Na concepção de 
A racionalidade na interpretação e aplicação do direito: do desafio kelseniano ao desafio dos bons argumentos

Kelsen, os aplicadores do Direito determinam o sentido das normas por sua vontade, utilizando "normas de Moral, normas de Justiça, juízos de valor sociais que costumamos designar por expressões correntes, como bem comum, interesse do Estado, progresso etc.” (KELSEN, 1962, p. 293).

Esse aspecto, contudo, não torna o processo de interpretação/aplicação do Direito necessariamente irracional, até porque são criticáveis as ideias do não cognitivismo ético e do subjetivismo moral diante das inevitáveis valorações inerentes às atividades humanas e da impossibilidade do conhecimento puramente descritivo (RABENHORST, 2003).

Ademais, deve ser levado a sério o dever de fundamentação das decisões judiciais, previsto no art. 93, IX, da Constituição Federal, que faz que a interpretação/aplicação do Direito não fique entregue ao irracional. Essa fundamentação serve justamente de limite ao aspecto volitivo dos aplicadores do Direito enquanto metódica que permite o controle público da decisão. Afinal, um Estado republicano não comporta exercício de poder a não ser na "qualidade de agente delegado da coletividade", que deve satisfação pelos seus atos (BARCELLOS, 2005, p. 45).

O novo Código de Processo Civil (Lei no 13.105/15, art. 489) (BRASIL, 2015, online) declara como elementos essenciais da sentença "os fundamentos, em que o juiz analisará as questões de fato e de direito", destacando que não se considera fundamentada uma decisão que "empregar conceitos jurídicos indeterminados, sem explicar o motivo concreto de sua incidência no caso", e que "não enfrentar todos os argumentos deduzidos no processo capazes, em tese, de infirmar a conclusão adotada pelo julgador" ( $\$ 1^{\circ}$, II, IV). Acrescenta que, "no caso de colisão entre normas, o juiz deve justificar o objeto e os critérios gerais da ponderação efetuada, enunciando as razões que autorizam a interferência na norma” ( $\$ 2^{\circ}$ ). Da mesma forma, os atos administrativos, que atingem direitos ou interesses do cidadão, "deverão ser motivados, com indicação dos fatos e dos fundamentos jurídicos” (Lei no 9.784/99, art. 50).

Entretanto, somente o dever de fundamentação e motivação não tem força suficiente para garantir a limitação ao aspecto volitivo do ato de interpretação do Direito, mormente quando o ambiente nada fizer contra eventuais abusos. Em perspectiva retórica, se o magistrado disser que "decide conforme sua consciência", se alegar que possui "notório saber", e por isso não precisa consultar a doutrina, ou se decidir abertamente contra o sentido literal da lei, e esta atitude for confirmada pelo ambiente da comunidade jurídica, "então é isso mesmo" (ADEODATO, 2014, p. 367s.).

O que interessa aqui é que o argumento kelseniano para objetar a racionalização da interpretação jurídica acaba sendo enfraquecido diante do dever de fundamentação dos operadores oficiais do Direito no Brasil. Nada impede que o elemento volitivo do 
aplicador seja justamente o de fazer a coisa que acredita certa cognitivamente, visto que não é mais aceitável tratar os juízos de valor, que guiam o processo de interpretação jurídica, como se fossem apenas ligados aos "impulsos, emoções e interesses de cada julgador, que escapam a qualquer controle da ordem jurídica" (KRELL; KRELL, 2016, p. 246).

Assim, a presença de elemento volitivo na interpretação do Direito não conduz a uma inevitável irracionalidade no seu resultado; a racionalização desse processo corriqueiro pode ser alcançada na medida em que a sua metódica for estudada e trabalhada melhor. Nesse sentido, o dever legal de fundamentação das decisões do Poder Judiciário permite um controle mais denso das suas decisões.

\section{A "MOLDURA NORMATIVA" E A "ÚNICA RESPOSTA CORRETA" COMO POSIÇÕES EXTREMADAS; A JUSTIFICAÇÃO RACIONAL DA DECISÃO JURÍDICA}

Como vimos, Kelsen entendia a aplicação do Direito por um órgão estatal como a ligação entre um ato de cognição, por meio do qual se reconhecem as (mais ou menos abrangentes) possibilidades de interpretação no caso concreto, e um ato de vontade, efetuado pelo "intérprete autêntico" para realizar a sua livre escolha discricionária entre as opções existentes.

Para ele, a norma de nível superior não pode vincular sob todos os aspectos o ato de sua aplicação, restando sempre uma margem (maior ou menor) de livre apreciação. A norma do nível superior sempre possui, em relação ao ato de produção ou de execução normativa, o caráter de um "quadro" ou de uma "moldura" a ser preenchido (KELSEN, 1962, p. 288s.).

A interpretação jurídica estaria sempre limitada à moldura de significado da respectiva norma. Todavia, as fronteiras dessa moldura normativa não são preestabelecidas pelos próprios enunciados linguísticos do texto como algo fixo, mas devem ser traçados por parte da ciência do Direito, cuja função seria encontrar as possíveis interpretações dos textos legais positivados.

Kelsen não informa quais seriam os métodos interpretativos aptos "para constatar os limites da norma, isto é, para traçar a moldura". Por isso, a decisão sobre o significado da norma no caso concreto cabe apenas ao "intérprete autêntico", ainda que a sua leitura seja amplamente rechaçada pela doutrina jurídica. Isso quer dizer que, no fundo, "tudo pode ser apresentado como situado dentro da moldura" (DIMOULIS, 2006, p. 211).

Esse resultado talvez surpreenda, mas é confirmado pelo próprio Kelsen quando alega que o órgão jurídico competente poderia também "produzir uma norma que se 
A racionalidade na interpretação e aplicação do direito: do desafio kelseniano ao desafio dos bons argumentos

situe completamente fora da moldura que a norma a aplicar representa" (KELSEN, 1962, p. 295). Por isso, "a moldura não deve ser tratada como um limite formal dentro da Teoria Pura do Direito" (CATÃO, 2013, p. 71), fato que, de certa forma, revela também que "o ponto fraco da teoria kelseniana não está na constatação da validade da interpretação oficial equivocada, mas na ausência de regras de interpretação da moldura" (DIMOULIS, 2006, p. 212ss.).

$\mathrm{Na}$ visão kelseniana, há, portanto, sempre, primeiro um ato cognitivo de interpretação, que é seguido por um ato volitivo. Este último se dá somente a partir do ponto em que o esforço intelectual não tenha levado a nenhum resultado concreto. Rechaça-se a ideia de que a "complementação" (ou integração) do Direito seja função legítima da dogmática jurídica (WALTER, 1990, p. 48s.).

Enquanto o juiz não abandonar o círculo da moldura legal, o positivismo kelseniano aceita que ele tome "a sua própria decisão", naturalmente motivada por aspectos político-ideológicos, o que torna inviável distinguir entre opiniões jurídicas (ainda) racionalmente defensáveis e outras, situadas além desse limite. Esse labor tão essencial ao progresso do Direito não é reconhecido como "científico", sendo, por isso, expulso da Teoria Pura. Aqui há confusão indevida entre razão jurídica e ideologia, categorias que podem e devem ser separadas: o raciocínio jurídico, que não se resume à estrita interpretação textual e à subsunção, não se transforma, necessariamente, em pensamento "político" (KRIELE, 1976, p. 60ss.).

A objeção kelseniana à possibilidade de se declarar certa interpretação como mais correta do que outra, quando ambas estão dentro da moldura normativa, representa o extremo oposto da ideia de uma "única resposta correta" na interpretação/aplicação do Direito. Segundo essa tese, introduzida por Dworkin (2002, p. 127ss.), não se permite uma discricionariedade judicial nos casos difíceis, que existem quando "uma ação judicial não pode ser submetida a uma regra de direito clara, estabelecida de antemão por alguma instituição".

Para o autor norte-americano, até nesses casos, sempre há só uma resposta correta, a ser produzida a partir dos "direitos enquanto trunfos" e dos princípios morais e jurídicos. O encontro dessa resposta é ilustrado pelas metáforas do "juiz Hércules" e do "romance em cadeia" (DWORKIN, 2014), com as quais ele defende uma teoria normativa do Direito, rejeitando a ideia positivista de teorização conceitual-descritiva. Nessa linha, uma Teoria Geral do Direito deve ser "ao mesmo tempo normativa e conceitual"; a parte normativa deve "conter uma teoria da legislação, da decisão judicial e da observância da lei” (DWORKIN, 2002, p. 8).

No caso brasileiro, prevalece a função do Legislativo de estabelecer textos normativos, assim como previsto na Carta de 1988. Para esse contexto, a proposta de Dworkin vai longe demais quando aceita como Direito os princípios morais. $\mathrm{O}$ fato de 
que existem textos legais que permitam mais de uma interpretação não significa que a sua interpretação/aplicação não pode ser feita a partir de critérios de racionalidade, aptos a eliminar pelo menos algumas possibilidades interpretativas. As tensões entre a legislação e a realidade não precisam ser resolvidas tão somente pelo legislador; nos casos mais difíceis, deslocam-se para o juiz e para a doutrina dogmática (FERRAZ JÚNIOR, 2015, p. 204).

A teorização do Direito deve abordar a questão da sua interpretação e aplicação, inclusive com uma teoria da decisão judicial, mas não precisa de uma formulação moral que presuma uma única resposta correta. Isso porque a tese a qual defende que haja somente uma resposta correta reconhece a impossibilidade de provar qual seria. Além disso, ela trabalha com a ficção exagerada do "juiz Hércules”, que levanta a pergunta de se este, em face dos possíveis recursos a instâncias superiores, transformar-se-ia em um "Meta-Hércules" (AARNIO, 1990).

Refletir sobre as relações de indeterminação do Direito e sua possível superação sobretudo a maneira adequada e justa de decidir um caso concreto - significa entrar em um campo que vai muito além de uma ciência "pura”. Apesar da junção racional de argumentos em favor ou contra uma solução, jamais será possível indicar apenas uma como a "única juridicamente correta" (WALTER, 1990, p. 51). Por isso, a ideia de que existe, em cada caso, apenas uma interpretação e decisão correta foi abandonada pela Teoria do Direito como modelo teórico, sendo ela discutida, hoje tão só como uma "possível suposição contrafática, sob o aspecto de sua função lógico-argumentativa" (NEUMANN, 2008, p. 329).

É preferível aprofundar a perspectiva da justificação da decisão como procedimento, já que é necessário conferir legitimidade e certeza à função judicial, o que pode ser alcançado apenas mediante o uso de argumentos apropriados. Somente assim é possível superar os extremos das teorias de Kelsen e Dworkin e cumprir o dever legal de fundamentação das decisões jurídicas.

Nessa mesma linha, Aarnio (1990) defende a melhor justificação possível, chamando os argumentos utilizados de "fontes do Direito", que variam segundo a cultura prevalecente. A justificação interna é caracterizada pelo silogismo aristotélico (modus ponens); há uma premissa normativa e uma fática, para se obter a decisão.

Nos casos difíceis, é sempre possível questionar as premissas de inferência, que devem ser objeto de argumentação; é essa a tarefa da justificação externa (ATIENZA, 2016, p. 33). Nela, é possível construir cadeias de silogismos e entimemas - estes também chamados de "silogismos retóricos" (ADEODATO, 2002, p. 261ss.) -, a fim de sustentar a premissa controvertida, que aparecerá como conclusão. Assim, a justificação externa se assemelha a um quebra-cabeça: o melhor resultado é o conjunto mais homogêneo, com a diferença de que, no quebra-cabeça normal, se sabe qual figura se irá 
A racionalidade na interpretação e aplicação do direito: do desafio kelseniano ao desafio dos bons argumentos

construir, enquanto no raciocínio jurídico, não se conhecem previamente os argumentos corretos. Por isso, procura-se a melhor justificação possível e não uma única resposta correta. Cada decisão de um caso difícil deve ser pautada por uma solução e uma justificação aceitável para a maioria dos membros racionalmente pensantes da comunidade jurídica (AARNIO, 1990).

Vê-se, portanto, que o esquema da moldura kelseniana é resultado de uma frustração de não se ter a priori uma única resposta correta para todos os casos, o que não impede que se busque uma melhor justificação possível para a solução dos casos, a fim de se racionalizar a interpretação/aplicação do Direito.

\section{O RELATIVISMO DE CONTEÚDO DO DIREITO POSTO E A INCOMENSURABILIDADE VALORATIVA}

Outra ideia problemática é o relativismo absoluto no conteúdo do Direito defendido por Kelsen. Em uma sociedade aberta, em que se "rejeita a autoridade absoluta do que é meramente estabelecido e meramente tradicional" (POPPER, 1974, p. 9), fica cada vez mais difícil se falar em moral estática com clareza de conteúdo, diante da liberdade e da abstração cada vez maiores das posições sociais dos indivíduos. Estes passam a compor uma sociedade de anônimos: contratantes, contratados, consumidores, empresários, políticos, juízes, professores, estudantes etc., cujos direitos lhe são conferidos em um plano ideal (POPPER, 1974). Isso faz que o relativismo ganhe espaço.

A impessoalidade, nessa concepção, toma conta das relações sociais oficiais, conforme a Constituição (art. 37) prescreve para a Administração Pública. Isso não impede tratamentos privilegiados para algumas classes ou pessoas, visando a alcançar finalidades da própria ordem jurídica, desde que seja direcionado para todos os indivíduos em semelhante situação. Apesar do pluralismo da sociedade aberta, que amplia o espaço do relativismo, não são admissíveis tratamentos indignos ou degradantes ao ser humano, seja pela orientação doutrinária baseada na história do constitucionalismo (NOVAIS, 2012, p. 45), seja pelo fato de que a Constituição de 1988 estabelece valores, entre eles a dignidade humana, que devem ser respeitados. Antes, tinha-se um positivismo jurídico excessivamente sistematizador, voltado para explicações racionais do Direito, o que acabou por gerar "filosofias irracionalistas e, na política, regimes totalitários" (LOSANO, 2010, p. 25).

Há quem afirme que os regimes autoritários se aproveitaram, de certa forma, das teorias positivistas dominantes na Europa nos anos 30. Para ascender ao poder, Hitler cumpriu, inicialmente, as exigências da Carta de Weimar, apesar de desprezá-la; as suas "Leis raciais de Nuremberg", de 1935, foram aprovadas no Parlamento, respeitando-se as 
formalidades. Por essa razão, o juspositivismo foi profundamente desacreditado na Alemanha do pós-guerra. Não é exagerado dizer que o positivismo jurídico fracassou como método filosófico do Direito para impedir a insegurança, a incerteza e as violações a direitos humanos. Para evitar que tais violações se repitam, o novo constitucionalismo brasileiro coloca o ser humano como prioridade institucional da ordem jurídica, em respeito à dignidade que merece (BARROSO, 2013, p. 145s.).

$\mathrm{Na}$ busca pela efetividade dos valores constitucionais, que servem como limites democráticos ao relativismo, Barroso (2013, p. 150ss.) reconhece que novamente foi utilizada uma estratégia positivista, elevando-se os valores constitucionais à qualidade de normas mediante positivação como princípios. Estes, por terem características especiais, exigem mecanismos próprios de interpretação/aplicação, como a ponderação. Nesse ponto, o constitucionalismo contemporâneo já se distanciou bastante da estratégia positivista, por desenvolver um procedimento voltado a justificar racionalmente a aplicação dessas normas especiais (BARCELLOS, 2005, p. 39ss.), algo, até então, visto como impossível de justificação científica.

Nesse caminhar, a Teoria do Direito, enquanto mera descrição, perde espaço para teorias normativas voltadas à aplicabilidade das normas jurídicas, não fundadas em considerações de Direito Natural ou da metafísica, mas nos valores presentes na própria Constituição, cuja função é a de limitar o espaço do relativismo do Direito, inclusive em seu aspecto de aplicabilidade.

A relatividade, assim, tem seu espaço diminuído, embora não eliminado. Hoje, quase ninguém defende que o testemunho de uma mulher valha menos do que de um homem ou que sejam mantidas as desigualdades sociais, contrariando o art. 3º, III, da CF. Ante os valores constitucionais, o problema da relatividade do conteúdo do Direito perde espaço para a questão da solução racional de colisões ou disputas entre valores. A relatividade é associada ao sopesamento de valores, que não têm, objetivamente, pesos predefinidos.

Alexy (2017, p. 593ss.) acredita, entretanto, na possibilidade de juízos racionais "sobre intensidades de intervenções e graus de importância" nos níveis "leve", "moderado" e "sério". Isso teria de ser observado no momento do sopesamento entre os princípios representativos dos valores distintos em disputa, a partir de uma fórmula específica. A “valoração concreta do valor”, contudo, não deixa de ser subjetiva: se dois princípios colidem, ambos podem ser defensáveis por razões aceitáveis ou nem colisão haveria, mas mera prevalência imediata. Pode-se concluir que os dois princípios têm o mesmo valor ou não há um método racional para estabelecer um valor diferente para cada um (GUIBOURG, 2015).

Seria, então, esse o ponto em que a racionalidade da interpretação/aplicação é impossível? Na verdade, não. Como dito antes, não existe apenas uma resposta correta, 
A racionalidade na interpretação e aplicação do direito: do desafio kelseniano ao desafio dos bons argumentos

de maneira que a produção de uma decisão pode ser racional, independentemente da possibilidade de se estabelecer previamente uma valoração "correta" sobre os valores em disputa. A decisão judicial deve se preocupar, para além de seu aspecto formal, com "certas regras de raciocínio e da lógica", com o "lado consensual" consistente na busca para o alcance de "concordância sobre as valorações que influenciam a interpretação e as ideias finalísticas sobre as consequências” (KRELL, 2014). O pensar argumentativo, nas questões de valorações, somente pode visar ao consenso mais abrangente possível.

Essa constatação significa que a interpretação/aplicação do Direito nos casos envolvendo valores em disputa, embora racional, pode ter resultados incertos. O desafio teórico é relacionado à objetividade possível na argumentação, para que haja certa previsibilidade das decisões jurídicas. O problema que resta a ser enfrentado tem sua origem na axiologização dos direitos fundamentais, que levou à adoção da ponderação como "a forma de aplicação por excelência dos direitos fundamentais" (SILVA, 2011, p. 364).

Os críticos que denunciam a subjetividade e a irracionalidade do sopesamento deveriam responder primeiro até que ponto o Direito pode ser racional ou objetivo, não somente no âmbito do sopesamento. A subjetividade existente na ponderação, entretanto, somente evidencia o déficit de racionalidade enquanto técnica decisória, caso o nível de racionalidade pretendido seja extremado demais, a ponto de se partir de um rígido padrão binário redutor que conhece apenas as posições "completamente racional" e "irracional". Muitas das críticas à ponderação limitam-se a denunciar o seu aspecto irracional e desconsideram o que ela pode oferecer para a justificação racional de decisões (LEAL, 2014).

\section{PODE HAVER OBJETIVIDADE NA INTERPRETAÇÃO/APLICAÇÃO DO DIREITO NOS CASOS DE VALORES EM DISPUTA? A IMPORTÂNCIA DOS "BONS ARGUMENTOS"}

Dreier (1979, p. 99) enfatiza que a resposta à pergunta de se assuntos éticos podem ser decididos racionalmente ou não depende da forma como se define a relação entre, de um lado, a possibilidade de uma realização aproximativa de princípios morais e, do outro, o seu "resto irracional praticamente inevitável". Independentemente dessa definição, não se justificaria declarar questões materiais de ética jurídica como "não científicas" e excluí-las da ciência do Direito, visto que "a medida de seu esclarecimento racional pode ser otimizada".

Racionalidade, objetividade e certeza precisam ser mais bem delimitadas nas críticas, para que não se exija um padrão ideal inalcançável. Se o desejo é de objetividade, o bom argumento também terá de ter certa objetividade, em uma 
equivalência de padrões. Vale dizer que, o padrão desejado ditará a qualidade do (bom) argumento. Este será racional nos limites do padrão de racionalidade possível, como será objetivo nos limites do padrão de objetividade possível e previsível nos limites do possível. Em geral, dever-se-ia admitir não ser possível um padrão de "racionalidade ou uma objetividade que exclua por completo qualquer subjetividade na interpretação e na aplicação do direito". Isso porque, "no direito, objetividade não pode ser sinônimo de demonstrabilidade inequívoca, ou sinônimo de única resposta correta faticamente demonstrável" (SILVA, 2011, p. 366s.).

Já que foi revelado ao longo do tempo que o resultado da interpretação jurídica não pode ser julgado em termos estritos de verdade científica, é preciso fornecer meios para poder diferenciar seus resultados pelo grau de racionalidade, a partir de uma base referencial que permita a atribuição, pelo menos aproximativa, de correção objetiva às opções do intérprete (FERNANDEZ, 2009, p. 107). Na ciência do Direito dos tempos atuais, parece ser mais plausível a adoção de teorias cujo conceito de verdade se orienta pela capacidade de as proposições normativas constituírem um consenso ou uma concordância potencial dos sujeitos envolvidos. Nesse sentido, a pretensão de alcançar uma verdade está na dependência de uma fundamentação convincente, por meio do emprego de argumentos racionais, o que torna a teoria científica do saber jurídico progressivamente uma teoria da argumentação jurídica (NEUMANN, 2002, p. 478s).

Essa teoria encontra na realidade do mundo jurídico uma arena da argumentação prática, pois aplicar o Direito significa, sobretudo, justificar a efetuação de juízos de valor em diferentes contextos (ROTTLEUTHNER, 1973, p. 204s). Ao mesmo tempo, é questionável a tentativa de posicionar a interpretação de normas jurídicas na simples dependência de fatos sociais empíricos, como consensos, opiniões dominantes ou expectativas (políticas) majoritárias da comunidade, visto que os respectivos processos de levantamento de dados sociológicos pretensamente "objetivos" também estarão quase sempre norteados por decisões valorativas e ideológico-políticas que influenciam (ou até predeterminam) os resultados (KRIELE, 1976, p. 102ss., 146).

A retórica ganha força nesse ambiente em virtude da impossibilidade de se trabalhar com o ônus de demonstrar a verdade; em vez disso, é preciso argumentar pela plausibilidade, o que acaba por estabelecer limites para padrões excessivamente exigentes de racionalidade, objetividade e certeza. A objetividade possível no Direito está ligada aos aspectos da possibilidade de controle intersubjetivo e da previsibilidade da decisão.

Uma boa argumentação precisa viabilizar o controle intersubjetivo e garantir certa previsibilidade, o que somente será alcançado mediante a ponderação, caso haja preocupação com outros três aspectos: o metodológico, que resulta na recusa de preferências sem fundamentação expressa; o teórico, que impõe a revelação da teoria 
A racionalidade na interpretação e aplicação do direito: do desafio kelseniano ao desafio dos bons argumentos

subjacente ao método utilizado; e o institucional, relacionado a precedentes e ao controle social por acaso existente (SILVA, 2011).

Essa boa argumentação, isto é, a possibilidade de alcançar a objetividade, racionalidade e certeza possíveis no Direito, em casos difíceis ou que envolvam ponderação, necessariamente precisará observar esses três aspectos. Em relação ao aspecto institucional, no Brasil, pode-se constatar a falta de padrões hermenêuticos mais apurados e de uma dogmática sofisticada para os intérpretes/aplicadores dos textos normativos (KRELL; KRELL, 2016).

Por outro lado, o novo Código de Processo Civil traz em seus artigos 926 e 927 um dever de respeito às decisões anteriores, enquanto condição de validade da própria decisão. Assim, eventual desrespeito à argumentação anteriormente solucionadora de um caso concreto e ao seu resultado significa invalidade da decisão não somente pela incompatibilidade material, mas também pela violação formal das balizas materiais já construídas, que significam bons argumentos para casos futuros. Por isso, conhecer o que é um bom argumento talvez seja a mais relevante condição para se conferir uma racionalidade com objetividade e, consequentemente, previsibilidade ao processo de interpretação/aplicação do Direito, que precisa de limites materiais.

O bom argumento, entretanto, não pode ser considerado fora do contexto da própria "natureza hermenêutica" do Direito, para que não se sobrestimem as críticas à falta de objetividade mais forte na delimitação dos bons argumentos. É por isso que a solução dos problemas que envolvem casos jurídicos costuma ser alcançada por meio de "pontos de vista" (topoi). Estes possuem poder de convencimento e reconhecimento geral, como as "verdades comuns convencionais", regras e máximas da razão prática, provérbios ou frases de sabedoria popular; na área do Direito, ainda há os padrões existentes na sociedade, além dos precedentes reconhecidos e das proposições doutrinárias (KRELL; KRELL, 2016, p. 237).

Nessa linha, um bom argumento nada mais é do que um raciocínio externalizado anteriormente - seja no âmbito teórico, seja no prático - e suficientemente capaz de servir de justificação racional para a solução do caso concreto, pelo seu compartilhamento teórico ou prático. Isso tornaria a argumentação dependente das decisões judiciais, aproximando-a do realismo interpretativo, em que as interpretações "autênticas" seriam os bons argumentos futuros, diante do elevado nível de publicidade das sentenças e de sua oficialidade. A argumentação igualmente ficaria dependente do desenvolvimento doutrinário, mormente em casos ainda não decididos pelo Judiciário. Assim, temas sem nenhuma tradição doutrinária ou judicial seriam temas com possibilidades menores de objetividade.

Bom é aquele argumento cuja utilização concreta recebe uma valoração positiva, que não pode ser de princípio valorado abstratamente, razão pela qual não é possível 
indicar um único conteúdo abstrato e universal apto a servir de critério à sua identificação. A partir de seu uso anterior, entretanto, torna-se viável sua valoração, com potencial de utilização em casos futuros. A objetividade possível do Direito é que leva a isso. A jurisprudência hermenêutica e a teoria realista da interpretação, embora divirjam em alguns aspectos, contribuem para a formação de um padrão decisório baseado na interpretação e nos limites da objetividade possível do Direito (JUST, 2014, p. 141ss.; 217ss.).

Por outro lado, é possível a existência de bons argumentos com intensidade maior de objetividade, geralmente utilizados para os casos "fáceis", que são os métodos tradicionais, os quais, embora não levem à verdade ou à decisão cientificamente correta, "servem como boas razões no processo discursivo de uma argumentação" (KRELL, 2014, p. 301).

Nesse ponto, a tradicional função contramajoritária do controle de constitucionalidade não passa de um bom argumento para justificar que as maiorias não podem abusar de sua posição de superioridade em detrimento das minorias. Assim, pode-se afirmar que os "novos papéis" do Supremo Tribunal Federal, propostos por Barroso (2017, p. 565ss.) - o representativo e o iluminista -, podem até ser criticados, mas possuem potencial para servir de bons argumentos nos casos em que se discuta uma eventual omissão legislativa ou a necessidade de um impulso na história. Bons argumentos, a bem da verdade, precisam tão somente ter um aspecto racional, não uma correção absoluta, em uma equivalência com o padrão de objetividade possível no Direito.

\section{A FUNÇÃO DA DOGMÁTICA JURÍDICA: DA OBSERVAÇÃO À PARTICIPAÇÃO NO PROCESSO DE INTERPRETAÇÃO/APLICAÇÃO DO DIREITO}

O conceito de ciência do Direito em Kelsen somente pode ser entendido a partir das suas teorias sobre o Direito e a ciência, as quais estão inseridas em certas condições históricas e aspirações ideológicas. Ao contrário da discussão contemporânea, que enfatiza a "lógica da opinião" (análise do discurso e da argumentação), a crítica da ciência jurídica nas primeiras décadas do século XX estava fixada na "lógica da verdade", exigindo a estrita neutralidade e isenção de valores da "jurisprudência”, com a nítida intenção de salvaguardar a autoridade da lei como fonte privilegiada do Direito (BOBBIO, 2008, p. 65ss., 79ss.). Deve ser lembrado que, para Kelsen, o Direito não é um fim, mas apenas um meio ("mecanismo coativo"), e que à Teoria Pura interessa somente a sua estrutura, não a sua função (BOBBIO, 2007, p. 204ss.).

A restrição kelseniana da função da ciência do Direito a expor apenas as 
A racionalidade na interpretação e aplicação do direito: do desafio kelseniano ao desafio dos bons argumentos

possibilidades de significado de uma norma, sem poder destacar uma delas como "a correta", contradiz tanto o autoentendimento como a práxis da dogmática jurídica. Ademais, gera o problema de deixar o juiz sem propostas qualificadas sobre as possibilidades de desenvolver, de maneira crítica e inovadora, o Direito (DREIER, 1981, p. 55,229 ss.).

Também não é possível separar a própria ciência (objetiva) do Direito da sua aplicação, permitindo-se manifestações subjetivas somente no âmbito da última. É justamente a sua função "tornar convincentes" as valorações que ela contém, "apesar de não lhes conferir caráter vinculante" (KIRSTE, 2013, p. 41). Até entre aqueles que se declaram "kelsenianos" ou adeptos da Teoria Pura, não há autor algum que apenas apresente o "elenco das interpretações possíveis da norma jurídica em estudo", abstendo-se de apontar qual entre elas seria a mais adequada (COELHO, 2013, p. 237).

O típico trabalho do profissional do Direito (seja ele juiz, administrador ou doutrinador) não se resume a descrever apenas as diferentes possibilidades interpretativas das normas, limitando-se a sistematizá-las e a analisar a sua aptidão para alcançar os fins colimados pelo legislador, sem o acréscimo de opinião (= valoração) própria. Uma das mais importantes tarefas da doutrina jurídica é justamente oferecer decisões claras ao operador prático, que têm o seu fundamento em interpretações "corretas", sustentadas por argumentos racionais e bem ponderados (AARNIO, 1979, p. 85-95).

Contra a visão de uma doutrina descritiva fala o próprio conceito da "jurisprudência", que, em países, como Alemanha, França, EUA ou Reino Unido, abrange tanto a atuação científico-acadêmica quanto a forense e a prática generalizada da ciência do Direito, cujos representantes costumam formular também juízos de valor. Assim, não é exagerado vislumbrar a jurisprudência como uma mistura de "fidelidade à lei, política jurídica, experiência própria e alheia, opinião pessoal, natureza da coisa, linguagem tradicional de fundamentação e decisionismo" (NAUCKE, 1972, p. 46 apud LÜDERSSEN, 2002, p. 212).

Assume a perspectiva de observador apenas aquele que pretenda descrever e/ou explicar a realidade jurídica de dada sociedade; ela é inspirada em um "interesse de conhecimento neutro a valores" do investigador, como o historiador ou o sociólogo. Diferentemente, a perspectiva de participante está direcionada ao conhecimento de dispositivos jurídicos sob a condição de que o próprio agente tenha parte na interpretação e na realização do Direito. Aqui, há um interesse prático, não isento de valores, o que faz o sujeito assumir uma posição que aprove ou rechace as normas levantadas na base de suas valorações.

Assim, a ciência do Direito "transporta o Direito para um contexto de fundamentação", cuja sistemática não se orienta apenas a textos legais e decisões 
judiciais ou administrativas (KIRSTE, 2013, p. 43). É a típica atitude do jurista profissional e da dogmática do Direito em geral usar argumentos dotados de uma pretensão geral de validade que clama por uma fundamentação sólida, com o fim de conquistar o consentimento dos outros. Nesse ponto, o antigo ideal da existência de princípios objetivamente válidos que orientam a avaliação e configuração do Direito, hoje, exerce a função de uma "ideia regulatória", a qual, "embora não condiga com a realidade, cumpre uma tarefa prática útil” (KOLLER, 1997, p. 47ss.).

Cumpre lembrar também que, diferentemente de outras áreas do saber, o Direito não conhece uma contraposição entre o enfoque teórico-interpretativo e o trabalho de aplicar leis a casos concretos, visto que as peças, petições, apelações, sentenças etc. produzidas pelos integrantes das profissões jurídicas sempre serão arrazoadas, empregando-se conceitos e categorias provenientes de reflexões teóricas mais abstratas (SALDANHA, 2003, p. 261).

Partindo-se de uma análise formal orientada por certos modos de sentença e julgamento, a dogmática jurídica aparece como uma mistura indissolúvel de assertivas empíricas, conceitual-analíticas e valorativas. Essa situação talvez seja pouco satisfatória do ponto de vista científico-teórico; entretanto ela faz muito sentido para a prática, já que o cientista dogmático não ocupa uma posição de mero observador externo (como nas ciências empíricas), mas age, igual ao juiz, na perspectiva de um participante cuja intenção é chegar, na base do Direito vigente, a resultados "racionais", "justos" e "adequados", com a diferença de que o juiz sempre deve tomar uma decisão, enquanto o cientista pode se restringir à análise e à descrição (RÜHL, 1998, p. 224ss.).

É de se perguntar também que juiz ou agente da Administração Pública levaria a sério a opinião de um cientista dogmático que se esquivasse de defender pessoalmente as necessárias valorações do resultado por ele sugerido, assumindo a posição de mero observador externo (KUHLEN, 1999, p. 35ss.). Mesmo um possível "distanciamento" da reflexão jurídica sempre tem intenções práticas: assume-se a posição de observador apenas para exercer melhor o papel de participante. A teoria jurídica pretende ser aplicada, isto é, nortear a práxis, da qual ela recebe seus conteúdos materiais e, assim, vem ganhando relevância (MASTRONARDI, 2009, p. 98).

Constata-se, com Dimoulis (2006, p. 218), que, "no âmbito da teoria da interpretação, a ausência de estudos construtivos sobre os métodos que permitem conhecer o conteúdo do material normativo compromete a credibilidade da abordagem juspositivista", tornando-a "um exercício acadêmico sem relevância cognitiva para o aplicador do direito". 
A racionalidade na interpretação e aplicação do direito: do desafio kelseniano ao desafio dos bons argumentos

\section{CONCLUSÃO}

Depois da abordagem das objeções kelsenianas à cientificidade da análise da interpretação/aplicação do Direito, resta observar que suas críticas são resultado do próprio conceito positivista de ciência que adota. Esse conceito, baseado nas ciências exatas e na comprovação empírica, levaram Kelsen a uma posição exacerbada de defender a mera descrição do Direito e de diferenciar rigidamente entre juízos de fato e juízos de valor, alegando que estes seriam inviáveis quanto ao conhecimento científico.

Essa distinção entre fatos e valores mostra-se tão subjetiva, artificial ou valorativa como a adoção de qualquer outra posição, a partir da ideia de que todo conhecimento é construído e não meramente constatado, como se fosse um espelhamento da natureza com base em uma mera presença. Essa orientação levou Kelsen a afirmar que a interpretação/aplicação do Direito seria resultado da prevalência da vontade sobre a racionalidade. Isso, porém, mostra-se incompatível com o dever de fundamentação das decisões judiciais estatuído na Constituição brasileira. A mera presença do elemento volitivo inerente a qualquer ato humano não impede que se interprete/aplique o Direito de forma racional.

Ainda que esse dever constitucional não tenha o condão de modificar, por si, as condições epistemológicas de produção de um conteúdo decisório por parte de um juiz, a compreensão kelseniana do problema facilmente levará ao esvaziamento da disposição constitucional. De qualquer maneira, a exigência da Lei Maior brasileira de que as decisões sejam fundamentadas obriga o decisor que apresente motivos coerentes, conquanto que estes não precisam corresponder, necessariamente, ao conceito de racionalidade empregado por Kelsen.

A ideia kelseniana acerca das possíveis diferentes interpretações dos textos normativos leva à posição extrema de que o limite da ciência do Direito seja a moldura das possibilidades de sentido. Por isso, não seria possível uma teoria racional da interpretação/aplicação do Direito, já que a preferência por uma das possibilidades nada mais é que vontade política. No lado oposto, Dworkin enfrenta a prevalência da vontade sobre a racionalidade a partir da proposição de que somente existiria uma única resposta correta para cada caso concreto.

O extremismo de ambas as posições leva à conclusão de que é mais apropriada para a realidade do sistema jurídico brasileiro a adoção da teoria da melhor justificação possível, cujos resultados são incertos, mas que obriga o intérprete/aplicador do Direito a verificar sempre a possibilidade de chegar a uma decisão razoavelmente objetiva e racional, principalmente em casos difíceis. Essa objetividade do Direito somente se dará em um sentido fraco, de forma que os bons argumentos componentes da melhor justificação possível seguirão sempre o padrão de objetividade possível do Direito. Isso, 
entretanto, não impede que se diga que a interpretação/aplicação do Direito pode ser racional.

Até hoje, há quem declare em congressos jurídicos, com ares de importância, que, perante a "confusão interpretativa" que predominaria nos tribunais brasileiros, com decisões subjetivas, imprevisíveis e mal fundamentadas, dever-se-ia "voltar ao positivismo de Kelsen”, como se este fosse um porto seguro no meio da tempestade. Cabe arguir se as lições positivistas, mormente as kelsenianas referentes à interpretação jurídica, realmente são capazes de remediar a doença ou se elas não fazem parte dos próprios fatores que causaram esse mal-estar no Brasil.

\section{REFERÊNCIAS}

AARNIO, Aulis. Denkweisen der Rechtswissenschaft: Einführung in die Theorie der rechtswissenschaftlichen Forschung. Wien/New York: Springer, 1979.

AARNIO, Aulis. La tesis de la única respuesta correcta y el principio regulativo del razonamiento jurídico. Doxa - Cuadernos de Filosofia del Derecho, Alicante, n. 8, p. 23-38, 1990.

ABBAGNANO, Nicola. Dicionário de Filosofia. Tradução Alfredo Bossi. 5. ed. São Paulo: Martins Fontes, 2007.

ADEODATO, João Maurício. Uma teoria retórica da norma e do direito subjetivo. 2. ed. São Paulo: Noeses, 2014.

ADEODATO, João Maurício. Ética e retórica: para uma teoria da dogmática jurídica. São Paulo: Saraiva, 2002.

AFTALIÓN, Enrique R.; VILANOVA, José. Introducción al Derecho. Buenos Aires: Abeledo-Perrot, 1994.

ALEXY, Robert. Teoria dos direitos fundamentais. Tradução Virgílio A. da Silva. 2. ed. São Paulo: Malheiros, 2017.

ANTISERI, Dario; REALE, Giovanni. História da Filosofia: de Freud à atualidade. Tradução Ivo Storniolo. São Paulo: Paulus, 2006. v. 7.

ATIENZA, Manuel. As razões do Direito: teoria da argumentação jurídica. Tradução Maria C. Cupertino. 2. ed. Rio de Janeiro: Forense Universitária, 2016.

BALLWEG, Ottmar. Phronetik, Semiotik und Rhetorik. In: BALLWEG, O.; SEIBERT, T.-M. (ed.). Rhetorische Rechtstheorie. Freiburg/München: Karl Alber, 1982. p. 27-71.

BARCELLOS, Ana Paula de. Ponderação, racionalidade e atividade jurisdicional. Rio de Janeiro: Renovar, 2005.

BARROSO, Luís Roberto. Contramajoritário, representativo e iluminista: o Supremo, seus papéis e seus críticos. In: GLEZER, R.; VIEIRA, O. V. (org.). A razão e o voto: diálogos constitucionais com Luís Roberto Barroso. Rio de Janeiro: FGV, 2017. p. 563 571. 
A racionalidade na interpretação e aplicação do direito: do desafio kelseniano ao desafio dos bons argumentos

BARROSO, Luís Roberto. O novo constitucionalismo brasileiro: Belo Horizonte: Fórum, 2013.

BOBBIO, Norberto. Da estrutura à função: novos estudos de Teoria do Direito. Barueri/SP: Manole, 2007.

BOBBIO, Norberto. Direito e poder. Tradução Nilson Moulin. São Paulo: UNESP, 2008.

BRASIL. Lei no 13.105, de 16 de março de 2015. Código de Processo Civil. Brasília, DF: Presidência da República, 2015. Disponível em: http://www.planalto.gov.br/ccivil_03/_ato2015-2018/2015/lei/113105.htm. Acesso em: 2 dez. 2018.

CALSAMIGLIA, Albert. Ciência jurídica. In: GARZÓN VALDÉS, Ernesto; LAPORTA, Francisco J. (ed.). El derecho y la justicia. 2. ed. Madrid: Trotta, 2000. p. $17-27$.

CARVAlHO, Paulo de Barros. Direito Tributário: linguagem e método. 5. ed. São Paulo: Noeses, 2013.

CATÃO, Adrualdo de Lima. Teoria do fato jurídico: uma abordagem lógica da decisão judicial. Curitiba: Juruá, 2013.

CHIASSONI, Pierluigi. O enfoque analítico na Filosofia do Direito: de Bentham a Kelsen. Tradução Heleno Torres e Henrique Mello. São Paulo: Contracorrente, 2017.

COELHO, Fábio Uchoa. Do desafio kelseniano à ruptura anticientificista. In: Oliveira, J. A. de; Trivisonno, A. T. G. (org.). Hans Kelsen: teoria jurídica e política. Rio de Janeiro: Forense, 2013. p. 235-252.

COSTA, Alexandre Araújo. Hermenêutica jurídica. Arcos, 1998. Disponível em: www.arcos.org.br/livros/hermeneutica-juridica/\#topo. Acesso em: 2 fev. 2019.

DECKERT, Martina. Recht und Wahrheit: zum gegenwärtigen Stand der Diskussion. Archiv für Rechts- und Sozialphilosophie - ARSP, v. 82, Heft 1, Stuttgart, p. 43-54, 1996.

DE GIORGI, Raffaele. Contingência e legitimação. Revista de Direito Administrativo, Rio de Janeiro, n. 254, p. 9-26, maio 2010.

DIMOULIS, Dimitri. Positivismo jurídico: introdução a uma teoria do direito e defesa do pragmatismo jurídico-político. São Paulo: Método, 2006.

DREIER, Ralf. Bemerkungen zur Rechtserkenntnistheorie. In: KRAWIETZ, W. et al (ed.). Argumentation und Hermeneutik in der Jurisprudenz. Berlin: Duncker \& Humblot, 1979. p. 89-105.

DREIER, Ralf. Recht - Moral - Ideologie: Studien zur Rechtstheorie. Frankfurt: Suhrkamp, 1981.

DWORKIN, Ronald. Levando os direitos a sério. Tradução Nelson Boeira. São Paulo: Martins Fontes, 2002.

112 - R. Opin. Jur., Fortaleza, ano 19, n. 32, p.85-116, set./dez. 2021 
DWORKIN, Ronald. O império do Direito. Tradução Jeferson Camargo. 3. ed. São Paulo: Martins Fontes, 2014.

FERNANDEZ, Atahualpa. Argumentação jurídica e hermenêutica. São Paulo: Imprensa Jurídica, 2009.

FERRAZ JÚNIOR, Tercio Sampaio. A ciência do Direito. 3. ed. São Paulo: Atlas, 2014. FERRAZ JÚNIOR, Tercio Sampaio. Função social da dogmática jurídica. 2. ed. São Paulo: Atlas, 2015.

FERRAZ JÚNIOR, Tercio Sampaio. Introdução ao estudo do Direito: técnica, decisão, dominação. 9. ed. São Paulo: Atlas, 2016.

GADAMER, Hans-Georg. Verdade e método I: traços fundamentais de uma hermenêutica filosófica. Tradução Flávio Meurer. 6. ed. Petrópolis: Vozes, 2004.

GUIBOURG, Ricardo. Alexy y su fórmula del peso. 2015. Disponível em: http://www.derecho. uba.ar/institucional/deinteres/2015-robert-alexy-guibourgcastellano.pdf. Acesso em: 1 dez. 2018.

JUST, Gustavo. Interpretando as teorias da interpretação. São Paulo: Saraiva, 2014.

KELSEN, Hans. Reine Rechtslehre. Mit einem Anhang: Das Problem der Gerechtigkeit. 2. ed. Wien: Franz Deuticke, 1960.

KELSEN, Hans. Teoria pura do direito. Tradução João B. Machado. 2. ed. Coimbra: Arménio Amado, 1962. v. 2.

KIRSTE, Stefan. Introdução à Filosofia do Direito. Tradução Paula Nasser. Belo Horizonte: Fórum, 2013.

KOLLER, Peter. Theorie des Rechts: eine Einführung. 2. ed. Wien usw.: Böhlau, 1997.

KRELL, Andreas J.; KRELL, Olga J. G. A importância do raciocínio retórico-tópico para uma melhor compreensão da dinâmica da argumentação jurídica na contemporaneidade. Quaestio Iuris, Rio de Janeiro, v. 9, n. 1, p. 244-271, 2016.

KRELL, Andreas J. Entre desdém teórico e aprovação na prática: os métodos clássicos de interpretação jurídica. Revista Direito GV, São Paulo, v. 10, n. 1, p. 295-320, jan. 2014.

KRIELE, Martin. Theorie der Rechtsgewinnung: Entwickelt am Problem der Verfassungsinterpretation. 2. ed. Berlin: Duncker \& Humblot, 1976.

KUHLEN, Lothar. Wertfreiheit in der Jurisprudenz? In: HILGENDORF, E.; KUHLEN, L. Die Wertfreiheit in der Jurisprudenz. Heidelberg: C. F. Müller 1999, pp. 33ss.

KUHN, Thomas S. A estrutura das revoluções científicas. Tradução Beatriz e Nelson Boeira. 12. ed. São Paulo: Perspectiva, 2013.

LARENZ, Karl. Metodologia da ciência do Direito. Tradução José Lamego. Lisboa: Fundação C. Gulbenkian, 2014. 
A racionalidade na interpretação e aplicação do direito: do desafio kelseniano ao desafio dos bons argumentos

LEAL, Fernando. Irracional ou hiper-racional? A ponderação de princípios entre o ceticismo e o otimismo ingênuo. Revista de Direito Administrativo \& Constitucional, Belo Horizonte, n. 58, p. 177-209, out./dez. 2014.

LOSANO, Mario G. Sistema e estrutura no Direito: o século XX. Tradução Luca Lamberti. São Paulo: Martins Fontes, 2010. v. 2.

LOSANO, Mario G. Introdução. In: KELSEN, Hans. O problema da justiça. São Paulo: Martins Fontes, 1996. p. 1-19.

LÜDERSSEN, Klaus. Gadamers Wahrheit für Juristen. Rechtsgeschichte, Frankfurt, n. 1, p. 208-215, 2002. Disponível em: http://rg.rg.mpg.de/en/article_id/15. Acesso em: 1 dez. 2018.

MAIHOFER, Werner. Rechtstheorie als Basisdisziplin der Jurisprudenz. In: ALBERT, H.; LUHMANN, N.; MAIHOFER, W.; WEINBERGER, O. (Hg.). Rechtstheorie als Grundlage der Rechtswissenschaft - Jahrbuch für Rechtssoziologie und Rechtstheorie. Band II. Frankfurt a.M.: Bertelsmann, 1972. p. 51-78.

MASTRONARDI, Philippe. Juristische Methode und Rechtstheorie als Reflexionen des Rechtsverständnisses. In: SENN, M.; FRITSCHI, B. (ed.). Rechtswissenschaft und Hermeneutik. Stuttgart: F. Steiner, 2009. p. 97-110.

MASTRONARDI, Philippe. Juristisches Denken: eine Einführung. Bern usw.: Haupt (UTB), 2001.

MELLO, Cláudio Ari. Democracia e epistemologia moral em Hans Kelsen. Revista Brasileira de Estudos Constitucionais, Belo Horizonte, n. 23, p. 655-694, jul./set. 2012.

MÜLLER, Friedrich. Teoria estruturante do Direito. Tradução Peter Naumann e Eurides de Souza. São Paulo: RT, 2008.

MURICY, Marília. Racionalidade do direito, justiça e interpretação. Diálogo entre a teoria pura e a concepção luhmanniana do direito como sistema autopoiético. In: BOUCAUlT, C. de A.; RODRIGUEZ, J. R. (org.). Hermenêutica plural: possibilidades jusfilosóficas em contextos imperfeitos. São Paulo: Martins Fontes, 2002. p. 103-125.

NEUMANN, Ulfrid. Recht als Struktur und Argumentation. Baden-Baden: Nomos, 2008.

NEUMANN, Ulfrid. Teoria científica da ciência do Direito. In: KAUFMANN, A.; HASSEMER, W. (org.). Introdução à Filosofia do Direito e à Teoria do Direito contemporâneas. Lisboa: Fundação C. Gulbenkian, 2002. p. 463-479.

NINO, Carlos Santiago. Introducción al análisis del Derecho. 11. ed. Barcelona: Ariel, 2003.

NOVAIS, Jorge Reis. Direitos fundamentais e justiça constitucional em Estado de Direito democrático. Coimbra: Coimbra Editora, 2012.

PERELMAN, Chaim. Lógica jurídica: nova retórica. Tradução Verginia Pupi. São Paulo: Martins Fontes, 2004.

114 - R. Opin. Jur., Fortaleza, ano 19, n. 32, p.85-116, set./dez. 2021 
POPPER, Karl R. A sociedade aberta e seus inimigos. O fascínio de Platão. Tradução Milton Amado. B. Horizonte/S. Paulo: Itatiaia/EdUSP, 1974. v. 1.

POPPER, Karl R. Die wissenschaftliche Methode (1934). In: Karl Popper Lesebuch. Ed.: David Miller. 2. ed. Tübingen: Mohr Siebeck (UTB), 2004.

PUTNAM, Hilary. Reason, truth and history. Cambridge University Press, 1981.

RABENHORST, Eduardo R. A normatividade dos fatos. João Pessoa: Vieira Livros, 2003.

REALE, Miguel. Teoria tridimensional do Direito. 5. ed. São Paulo: Saraiva, 1994.

ROTTLEUTHNER, Hubert. Rechtswissenschaft als Sozialwissenschaft. Frankfurt: Fischer, 1973.

RÜHL, Ulli F. H. Tatsachen - Interpretationen - Wertungen: Grundfragen einer anwendungsorientierten Grundrechtsdogmatik der Meinungsfreiheit. Baden-Baden: Nomos, 1998.

SALDANHA, Nelson. Ordem e hermenêutica. 2. ed. Rio de Janeiro/São Paulo: Renovar, 2003.

SILVA, Virgílio Afonso da. Ponderação e objetividade na interpretação constitucional. In: BARBIERI, C. H.; MACEDO JÚNIOR, R. P. (org.). Direito e interpretação: racionalidade e instituições. São Paulo: Saraiva, 2011. p. 363-380.

VIEHWEG, Theodor. Tópica e jurisprudência: uma contribuição à investigação dos fundamentos jurídico-científicos. Tradução Kelly Alflen. Porto Alegre: Sergio Fabris, 2008.

WALTER, Robert. Philosophische Hermeneutik und Reine Rechtslehre. In: VETTER, H.; POTACS, M. (ed.). Beiträge zur juristischen Hermeneutik. Wien: Literas, 1990. p. 41-52.

WIEACKER, Franz. Zur praktischen Leistung der Rechtsdogmatik. In: BUBNER, R. et al. (ed.). Hermeneutik und Dialektik - Festschrift für Hans-Georg Gadamer - Bd. II. Tübingen: Mohr, 1970. p. 311-336.

\section{NOTA}

Declaramos que o artigo intitulado "A racionalidade na interpretação e aplicação do Direito: do desafio kelseniano ao desafio dos bons argumentos", submetido à Revista Opinião Jurídica, representa fruto das pesquisas desenvolvidas pelos autores no âmbito da disciplina "Hermenêutica e argumentação jurídica em tempos de Neoconstitucionalismo: interpretação e efetivação dos direitos fundamentais”, do curso de Mestrado em direito da Universidade Federal de Alagoas, tendo ambos realizados as tarefas de sua elaboração e revisão da seguinte forma: 
A racionalidade na interpretação e aplicação do direito: do desafio kelseniano ao desafio dos bons argumentos

1) Andreas J. Krell desenvolveu de forma mais específica a prevalência da vontade na interpretação do Direito e a obrigatória justificação das decisões judiciais; a discussão dos conceitos da "moldura normativa" e da "única resposta correta", além da justificação racional da decisão jurídica com "bons argumentos"; a função da dogmática jurídica que deve participar do processo de interpretação/aplicação do Direito. Para tratar desses temas, levantou a bibliografia germânica referenciada.

2) Vitor Mendonça Maia desenvolveu de forma mais específica a descrição do "desafio kelseniano" e de sua importância no âmbito da interpretação jurídica; a discussão sobre a separação rígida entre Direito e Moral e a possibilidade de um discurso de justificação sobre juízos de valor na ciência do Direito; o relativismo de conteúdo do Direito posto e a incomensurabilidade valorativa; a fixação num modelo único de ciência e a afirmação do Direito como ciência prática.

\section{Como citar este documento:}

KRELL, Andreas Joachim; MAIA, Vitor Mendonça. A racionalidade na interpretação e aplicação do direito: do desafio kelseniano ao desafio dos bons argumentos. Revista Opinião Jurídica, Fortaleza, v. 19, n. 32, p. 85-116, set./dez. 2021. 